Article

\title{
The (Evolving) Vineyard's Age Structure in the Valencian Community, Spain: A New Demographic Approach for Rural Development and Landscape Analysis
}

\author{
Ilaria Zambon ${ }^{1,2, *(D)}$, Artemi Cerdà ${ }^{2} \mathbb{D}$, Sirio Cividino ${ }^{3}$ and Luca Salvati ${ }^{4}$ \\ 1 Department of Agricultural and Forestry Sciences (DAFNE), Tuscia University, Via San Camillo de Lellis, \\ I-01100 Viterbo, Italy \\ 2 Soil Erosion and Degradation Research Group, Department of Geography, University of Valencia, \\ 46010 Valencia, Spain; artemio.cerda@uv.es \\ 3 Department of Agricultural, Food, Environmental and Animal Sciences, University of Udine, \\ via delle Scienze 206, 33100 Udine, Italy; agricolturasicura@gmail.com \\ 4 Council for Agricultural Research and Economics (CREA), Viale S. Margherita 80, I-52100 Arezzo, Italy; \\ luca.salvati@crea.gov.it \\ * Correspondence: ilaria.zambon@unitus.it
}

Received: 2 March 2019; Accepted: 18 March 2019; Published: 20 March 2019

\begin{abstract}
Vineyards have assumed a key role as rural landmarks in recent decades. Investigating vineyard dynamics and contexts may reveal various economic, cultural, and environmental aspects of rural landscapes, which can be linked to land-use changes and major soil degradation processes, including soil erosion. As a contribution to rural landscape studies, the purpose of this work is to investigate the spatial distribution of vineyard plots in the Valencian community, located in the eastern area of the Iberian Peninsula, focusing on the final product, the type of vineyard and how long each vineyard has been settled over time. The work provides a comprehensive analysis of a wine-growing landscape, considering strategic (spatial) assets in present and past times. Vineyards were interpreted as a distinctive landmarks that give value to local economies; basic knowledge of how long different types of wine plots have been present in the Valencian community is useful when estimating their degree of sustainability and formulating suggestions, policies, and strategies to prevent processes of landscape degradation at various spatial scales.
\end{abstract}

Keywords: vineyards; age class; land-use change; landscape structure; soil degradation

\section{Introduction}

In the last few decades, vineyards have assumed a key role in the primary sector. Their recent expansion in several rural areas in Mediterranean Europe reflects a cultural heritage (re)acquired from a local product revalued over time. In respect to other agricultural crops, the cultivation of wine provides high economic profitability [1,2], and determines both positive and negative socio-environmental impacts and implications [3].

Among emerging concepts, the 'terroir' notion was introduced to highlight the contribution of vineyards to cultural, social, and economic heritage [4,5]. Around the world, the Mediterranean agricultural landscapes in Europe achieve a multifunctional role that surpass the traditional production of commodities and food, by providing further advantageous services, e.g., socioeconomic viability of rural areas and protection of biodiversity [6-11].

The impact of vineyards was primarily focused on a plot scale, applying biophysical approaches [12-14] and interpretative frameworks more oriented to social sciences [15,16]. However, a 
broader analysis of spatial and temporal changes in vineyards is required to offer a more comprehensive interpretation of landscape complexity in rural Mediterranean contexts $[17,18]$. A specific and additional objective is to address complex socioeconomic dynamics vis à vis current challenges [19,20], e.g., climate change [17,21,22], soil degradation, [23-25] and desertification [5,26-31].

From the environmental point of view, concerns about the negative impact on soil quality, as well as the occurrence land and water losses due to non-sustainable management of vineyards have frequently emerged [32]. Vineyards produce the highest soil and water losses [27-30]. For instance, other Mediterranean orchards, e.g., persimmon [33], citrus [34,35], olive [9,36,37], apricots, [38] and avocado, [39] bring more sediment and water than neighboring natural areas [3]. Vineyards are a tree crop associated with environmental vulnerability [27-30,40] due to their lack of leaf cover during the winter and low plant cover in summertime [3,30,41-47]. Generally, the main driving factors of soil erosion in vineyards are: (i) lack of vegetation; (ii) high slope angles; (iii) weak soil aggregate permanency; (iv) risky rainfall events, permitting rapid raindrops access to the soil surface; (v) intensive tillage; (vi) applied chemicals that increase soil contamination; and, (vii) nutrient impoverishment due to the lack of organic fertilization [48-50].

Today a conflicting situation is caused by the recent growth of the (highly profitable) wine-growing regions in Mediterranean landscapes; on the one hand, there is an increase in wine consumption and the use of intensive management techniques due to the high demand (and appreciation) of wine in the economic market $[13,26]$, on the other hand, wine cultivation has led to a decrease in local biodiversity and high rates of soil erosion and degradation in several local landscapes [50,51]. Some improvements to reduce soil losses in vineyards, e.g., the use of organic farming strategies [52], have been implemented. At the same time, enduring plant cover is useful for managing rural land and water resources in a sustainable way and consequently preventing soil erosion and desertification processes $[53,54]$.

Recently, researchers have shown that the age of vineyards can portray a key factor of environmental sensitivity, useful for monitoring soil erosion processes [3]. In fact, the planting of new vineyards leads to an increase in soil erosion, possibly leading to greater exposure to land degradation $[31,55]$. Therefore, the areas that are both (i) more prone to intensive wine production and (ii) more sensitive to higher erosion rates [27] seem to coincide with the youngest vineyards [55]. While, older root systems can reinforce hillslopes against erosion better than young root systems [55]. Due to this discovery, recent studies are increasingly dealing with the impact and influence of the age of plantation on forested soils and agricultural fields with trees $[3,55,56]$.

Based on these premises, the purpose of the present work is to analyze how vineyard plots are distributed in the Valencian community, located in the Iberian Peninsula. Studying each plot according to age, type of vineyard, and the final product provides a contribution in the analysis of rural landscapes dominated by vineyards of different ages and functions. Studies on the demographic balance of vineyards by age class are relatively recent. For instance, one example came from Italy and covered a relatively short period [56] and another came from the Southern Spain [3]. Vineyards were considered a distinctive landmark of the local economy and rural landscape in the Valencian community, a typical Mediterranean region. Distinguishing different types of wine plots, their spatial distribution, and their age, the present analysis contributes to a broader reflection on rural landscape development and sustainability, allowing formulation of informed suggestions, policies, and strategies to prevent soil degradation processes.

\section{Materials and Methods}

\subsection{Study Area}

The Valencian community is located along the Mediterranean Sea coast on the eastern side of the Iberian Peninsula (Figure 1), and extends along a coastal line towards the mountains, presenting a variety of representative Mediterranean environmental conditions. The Valencian Community is 
divided into three provinces, Valencia is the capital city and the third largest metropolitan area in Spain (indicated with a star in Figure 1), Castellón de la Plana, and Alicante. The area has $518 \mathrm{~km}$ of coastline on the Mediterranean Sea, covering a total area of $23,255 \mathrm{~km}^{2}$, with 4.5 million inhabitants and 534 municipalities. The entire region can be classified a Mediterranean climate regime, even if the western area has a more continental climate with less humidity and broader diurnal swings.

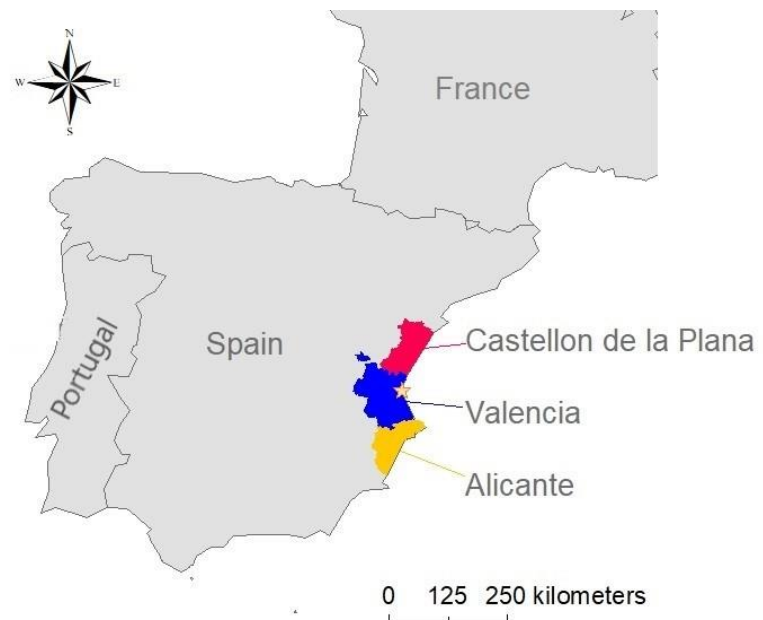

Figure 1. The Valencian community, its three provinces (Castellon de la Plana, Valencia, and Alicante), in Spain.

Spain is the second-largest producer of grapes for wine in Europe, encompassing $29.6 \%$ of Europe's yearly wine production $[53,57]$. The Valencian community is known for its traditional vineyard areas, which also produce quality products [58,59]. Valencia is responsible for $5 \%$ of the enological production in Spain since it is the fourth most extensively planted area with 61,226 hectares under vine crop. Valencia district was initially recognized for its bulk wine, the Bobal wine, which is native to this area and is the third most widely planted grape in Spain; other cultivars are Airén and Tempranillo.

Three distinct DOs (denomination of origin) were officially located within Valencia's boundaries: (i) the southern area in Alicante, (ii) the most inland region of Utiel-Requena, and (iii) Valencia. DO wines have to be produced and processed in a defined area and enjoy great commercial prestige because of their origin (at least 5 years, with prior geographical protection). Vine quality and characteristics depend on contextual factors, which include natural and human conditions. Only Utiel-Requena is considered a contiguous area, while both Alicante and Valencia consist of distinct portions of land connected within a normative DO district.

\subsection{Data and Variables}

The available data from the Agrarian Studies Service of the Generalitat Valenciana were collected and processed. As a snapshot of today's situation, data refer to all existing vineyard plots in the Valencian community. Therefore, it is not possible to study how many vineyards have been lost over time, but the present study explores how long the current vineyards (2017) have enriched the rural landscape in the region, considering the vineyard's age structure from a demographic point of view. Data describe all the rural plots intended for viticulture indicating the type of wine cultivated, the year in which each vineyard was planted, if each vineyard is labeled as protected designation of origin, the surface area occupied by each plot, and in which municipality it falls.

Through analysis we evaluated the surface area occupied by type of wine and final use of the wine produced in each parcel. Each wine parcel was dated according to the year of its planting, which was useful in defining how long it has been present in the Valencian landscape. Based on this information, the periods of greatest expansion of the vineyards (both in number of plots and extension of occupied surface area) can be identified (also according to the final product cultivated). By these 
means, it is conceivable to detect in which time period a greater fragmentation of vineyards took place. Indicators were illustrated on maps by means of a Geographic Information System (ArcGIS release 10.x, ESRI Inc., Redwoods, CA, USA). In this way, vineyard distribution can be detected at different spatial scales (from local to regional), offering a comprehensive analysis of vineyards' landscape in the Valencian Community.

\section{Results}

\section{Descriptive Analysis}

In 2017, about 71,000 ha were devoted to wine production in the Valencian Community. Three basic indicators are represented in maps (Figure 2):

- the number of wine parcels in each municipality (a);

- the density of wine parcels understood as the number of parcels on the municipal surface area (b);

- $\quad$ and the average age of wine parcels by municipality (c).

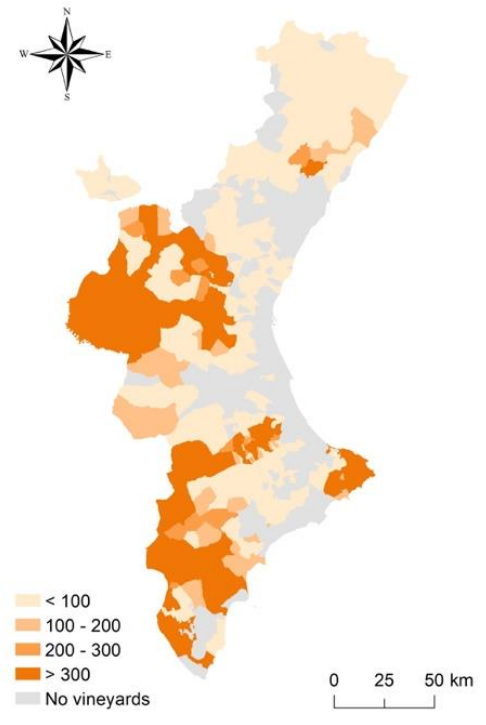

(a)

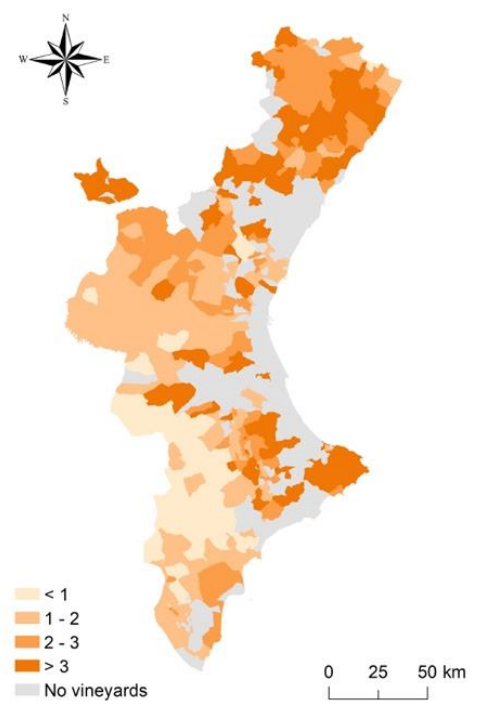

(b)

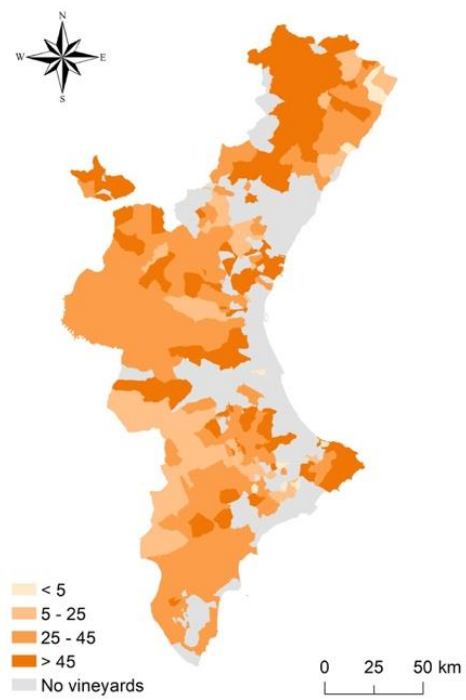

(c)

Figure 2. Number of wine parcels in each municipality of Valencian community (a); density of wine parcels (b); and average age of wine parcels per municipality (c).

The greatest landscape fragmentation of vineyards was observed inland of the Valencian community, but also in local contexts where the average age of the vineyards is around 5 and 25 years. The northern area displays a more homogeneous and dense vineyard landscape, revealing a historical presence of vineyards. On average, many northern municipalities recorded an average age of their existing plots above 45 years.

Eight out of ten vineyards in the Valencian Community were cultivated for winemaking processes (' $\mathrm{V}$ ' in Figure 3). Table wine ('M') was also appreciated in the area and represents $17 \%$ of the cultivated wine. Moreover, a good portion of land in Valencia's province was destined to the cultivation of mother vine variety $(1 \%)\left({ }^{\prime} \mathrm{PM}^{\prime}\right)$. Few parcels were also designated to satisfy family consumption, experimentation and wine passification (to make "passito" wine). The wines that are produced by the oldest plots include: Garnacha Peluda, about 67 years old on average; Leopoldo III (65 years old); Zalema (62 years old); and Grumier Tinto (60 years old). The youngest vineyards preferentially produce Marselan and potential graft mother vine variety. 


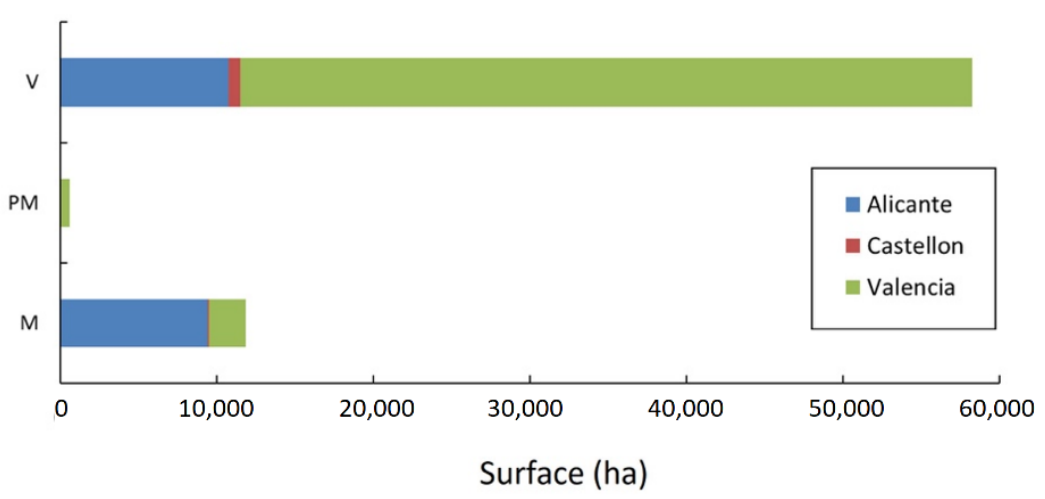

Figure 3. Type of wine cultivated (winemaking processes: ' $\mathrm{V}^{\prime}$; table wine: ' $\mathrm{M}$ '; mother vine: 'PM') in each province of the Valencian Community.

As well as providing a source of income for the agricultural economy, vineyards are a characteristic landscape in the Valencian community. Following a 10-year historical series, they have experienced a considerable expansion in the 1960s and 1970s (Figure 4). About $23 \%$ of the existing vineyards were specially planted in the 2000s. Mainly vineyards are dedicated to winemaking, while the current vineyards used only to make table wine were planted mostly among the 1970s and 1990s. Consequently, the largest area for table wine vineyards was established specifically in those years, offering more commercial wines in the economic market. Figure 4 reports a current assessment of vineyards (in 2017), following their planting year ( $x$-axis) and surface areas in the Valencian community (y-axis, in mega hectares) according to each final wine product. Other uses of the wine have been reported with other $\left({ }^{\prime} \mathrm{O}^{\prime}\right)$ but have a minimal relevance as can be seen from the Figure 4.

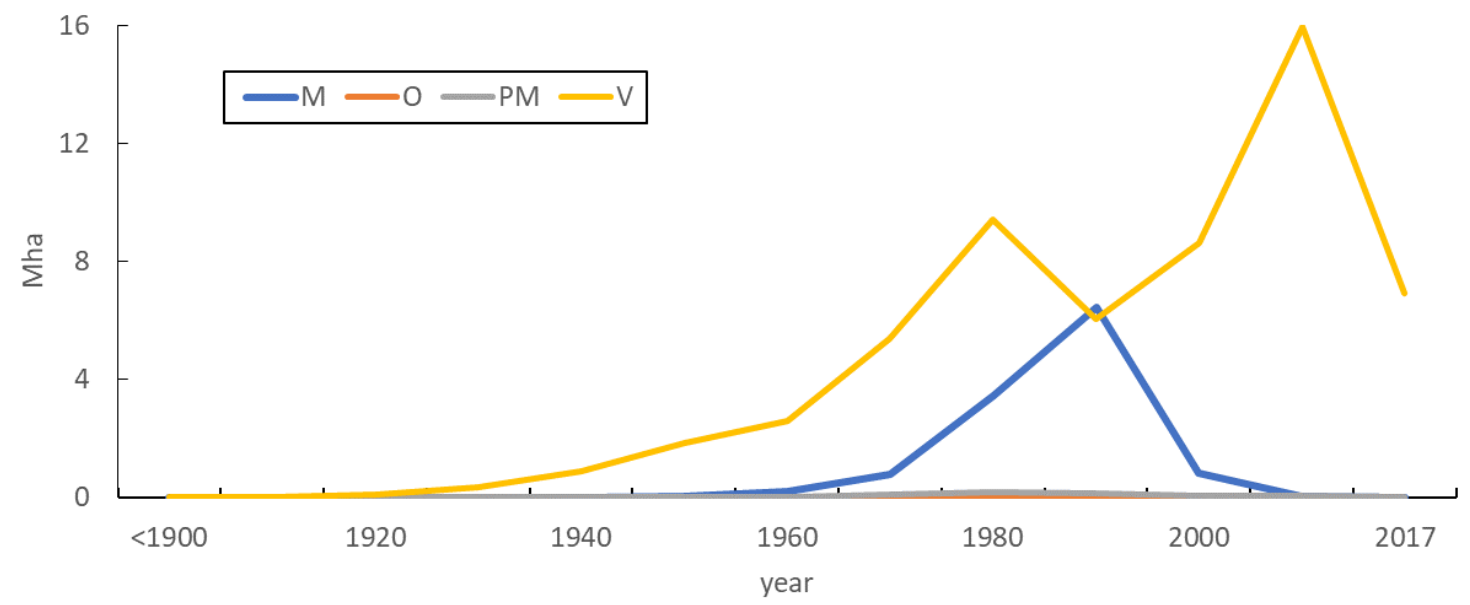

Figure 4. Time period of plantation (x-axis) and surface area in the Valencian community (y-axis, in mega hectares) by final wine product.

In addition to observing the surface area occupied by each vineyard planted by year, the number of plots can be extracted depending on the period of planting (Figure 5). The 1970s and the 1980s were the periods with the highest fragmentation of vineyard areas. In fact, $21 \%$ of existing wines were planted in these two decades. After this period, a reduction in the fragmentation of vineyards occurred in 1990-2000, increasing drastically in 2000-2010, and then decreased slightly in the last period. During the 1970s and the 1980s, the greatest fragmentation came from a demand for vinification and table wine; whereas, vineyards were planted mainly for wine in the 2000s. 


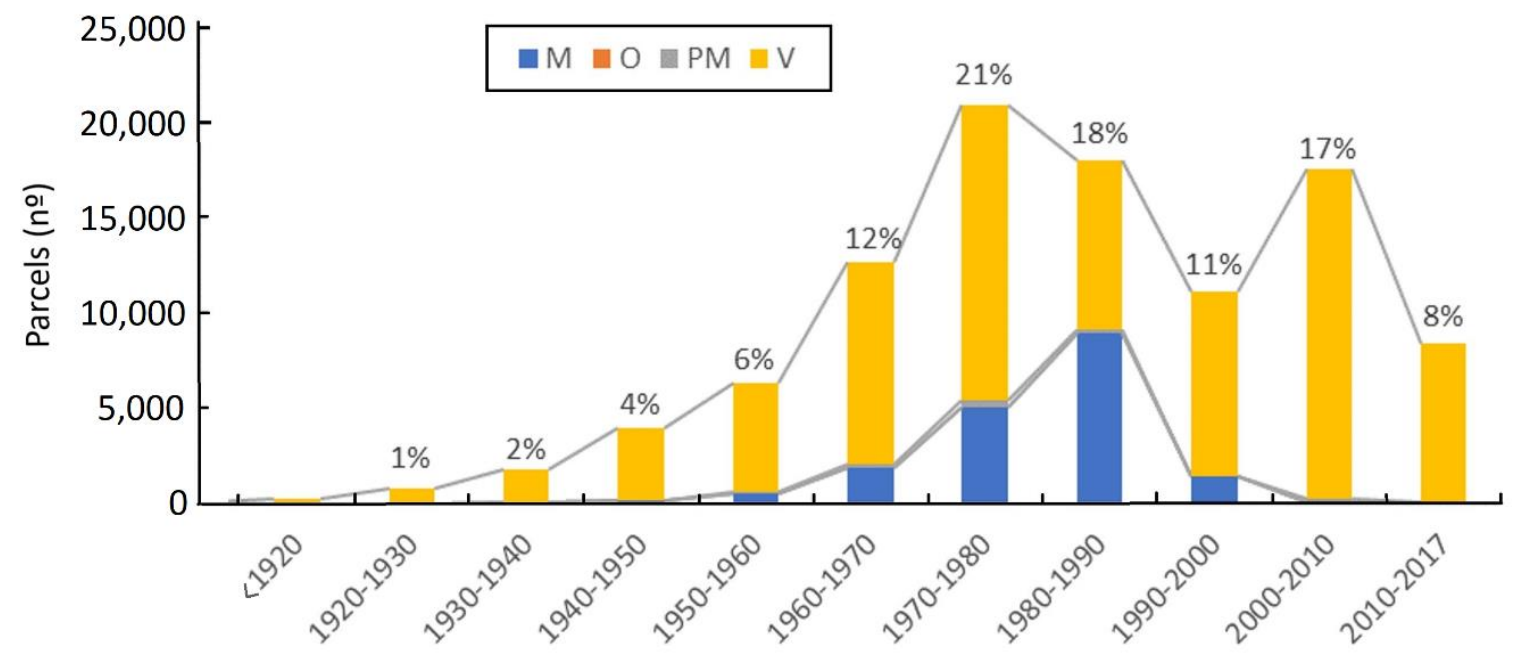

Figure 5. Time period of plantation (x-axis) and number of parcels planted in the region (y-axis, in hectares) according to each final product of wine.

In line with the spatio-temporal evolution of vineyards, the most successful types of wine were also detected. Considering the vineyards that today cover an area greater than 100 ha at a regional scale, the most characteristic wines are: Macabeo, Moscatel Malaga-De Alejandria-Romano, Italian Moscatel, Monastrell (Garrut), Tempranillo and Bobal. Considering 10-year intervals, planting of vineyards has mainly occurred in two decades: 1970-1980 and 2000-2010 (Figure 6).

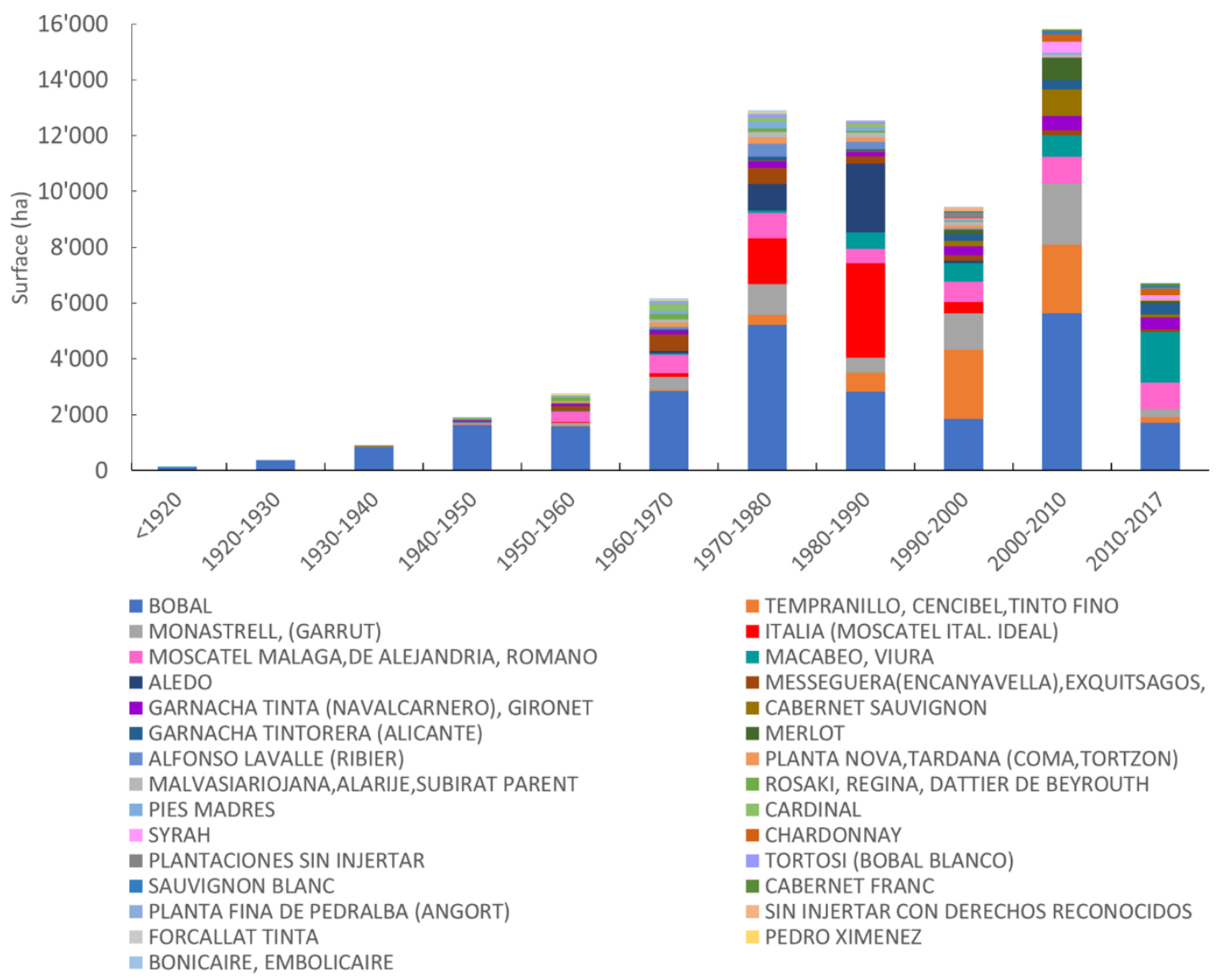

Figure 6. Type of wine (x-axis) and the relative surface area occupied in the region (y-axis, in hectares). 
A total of $61 \%$ of the vineyards recorded in 2017 were labelled as DO: 15,288 ha planted in DO Alicante, 12,963 hectares in DO Utiel-Requena, and 14,723 ha in DO Valencia (Figure 7). There is also the IGP Castelló (wine with protected geographical indication) which covers about 35 ha. D.O. Alicante and D.O. Valencia included the most fragmented vineyard areas even though they have many hectares dedicated to the production of wine. On average, D.O. Valencia has younger vineyards and greater spatial fragmentation. However, the IGP Castelló is concentrated in some small areas in the northern part of the Valencian community, with a higher average age of existing vineyards. Wines with a protected geographical indication are produced following specific regulations that are less demanding compared to DO regulations, e.g., at least $85 \%$ of the production should come from the protected area.

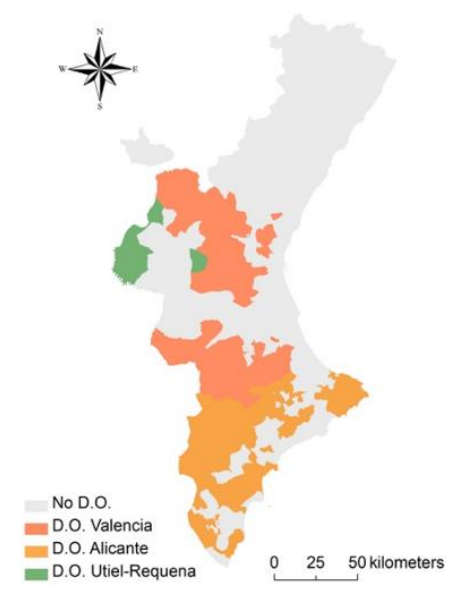

\begin{tabular}{|c|c|c|c|}
\hline D.O.s name & $\begin{array}{c}\text { D.O. } \\
\text { Alicante }\end{array}$ & $\begin{array}{c}\text { D.O. Utiel- } \\
\text { Requena }\end{array}$ & $\begin{array}{c}\text { D.O. } \\
\text { Valencia }\end{array}$ \\
\hline Surface area (ha) & $15,288.4$ & $12,963.2$ & $14,723.5$ \\
\hline Plots $\left(\mathrm{n}^{\circ}\right)$ & 21,901 & 14,506 & 24,331 \\
\hline Average age (years) & 37 & 36 & 34 \\
\hline
\end{tabular}

Figure 7. Denomination of origin (DO) in the Valencian community and selected indicators.

\section{Discussion}

Vineyard productivity and quality are intensively affected by plant age and modifications may require that a new plantation is set replacing the earlier one [56]. However, the age of the vineyards has been poorly studied since now. Only recently, an in-depth study was proposed focusing on soil erosion $[3,41-44,46,47]$. The importance of exploring vineyard contexts implies different environmental repercussions, but also, they can be linked to land-use changes and variation in rural landscape and intrinsic stimuli from local markets [2,48-60].

Joined "spatial patterns" and "temporal processes" and phenomena through spatial-temporal examination tools to discover the pattern of dynamic processes should be used to study land-use dynamics and strengthen the spatio-temporal feature-oriented investigation at the regional scale [61,62]. The "temporal fragmentation" in the present work, the higher number of vineyard plots planted in one period compared to another, explains several issues, e.g., dissimilar market trends at the regional scale, notables depending on the final wine produced (e.g., winemaking or table wine). Furthermore, the presence of subsidies or market interests are possibly linked to labelled wines that provide farmers a greater income. Furthermore, the presence of diseases may have burdened specific plants which were planted during a certain period [56].

Vineyards in the Valencian community experienced a considerable expansion since the 1960s-1970s, highlighting two decades of peak growth in 1970-1980 and 2000-2010. They are mainly dedicated to winemaking, even if in the 1970s and 1990s table wine was intensively produced. Therefore, the largest area for table wine vineyards were used give space to those producing-wines: this result highlights a relationship of change according to the type of wine, the year of planting and its final use. Furthermore, 1970-1980 is the temporal period that caused a greater fragmentation of the vineyard areas. In fact, $21 \%$ of the existing wines were planted in this period. Though, after this period, a reduction in the fragmentation of vineyards occurred in 1980-2000 and then dramatically 
increased in 2000-2010, and then slightly decreased in the last period. The "temporal fragmentation" explains a higher number of vineyard plots planted in the defined period compared to another. For instance, during the period between 1970-1980, the greatest fragmentation came from a demand both for vinification and table wine, while in the period between 2000-2010 recent vineyards were planted mainly for wine. Correspondingly, according to D.O. wine, it is possible to read spatial-temporal fragmentation. Valencia D.O. exposed the most fragmented vineyard areas even though they have many hectares dedicated to the production of wine. On average, D.O. Valencia has vineyards of younger age and greater spatial fragmentation.

The analysis also permitted the subdivision of different areas between them. Most municipalities have a high extension of vineyards dedicated to winemaking and are composed of fragmented parcels. The other areas diverge by different indicators. Few areas are dedicated to table wine cropped in numerous and fragmented plots; other areas exposed a high density of vineyards, since they occupy large territorial areas, especially dedicated to table wines, but the plots are less fragmented. And finally, some municipalities take up older contexts in terms of minimum age and average age. Given this characteristic, in this group emerge the vineyards intended for mother vines.

Furthermore, the study carried out may be linked to other research intended to identify the areas with younger vineyards and more prone to erosion processes [63-66]. The area that needs to be more attentive to erosion processes is the southern part of the Valencian community, as they have a dispersive density of vineyards and a very low average age compared to other regional areas. These areas (e.g., the municipalities of Ayora, Enguera and Moixent) are more sensitive since the combination of types of crops (vineyards) and frequent new planting can cause a higher probability of soil erosion, which is exacerbated by a climate composed of very dry summers, which makes water not able to penetrate the soil during periods of rain, prompting more intense phenomena of soil erosion (Figure 8a,b). As already reported by [3], the age of the vineyards and the presence (or absence) of ridges developed by tillage are responsible for the dis-connectivity of the rural system, and consequently reduce soil erosion rates. Furthermore, a probable solution could be to increase the density of vineyards and therefore their vegetation cover, which then can restrict erosion processes [67-69] and set a limit on the number of new plantings. Particularly, new plantings should follow a suitable management and planning approach for more sustainable agricultural practices, with the intention of restraining negative impacts on the environment and the landscape (Figure 8c,d).

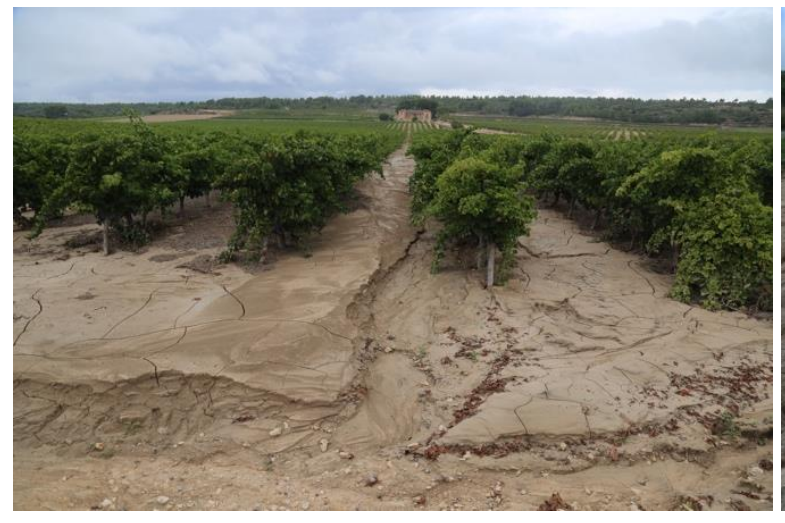

(a)

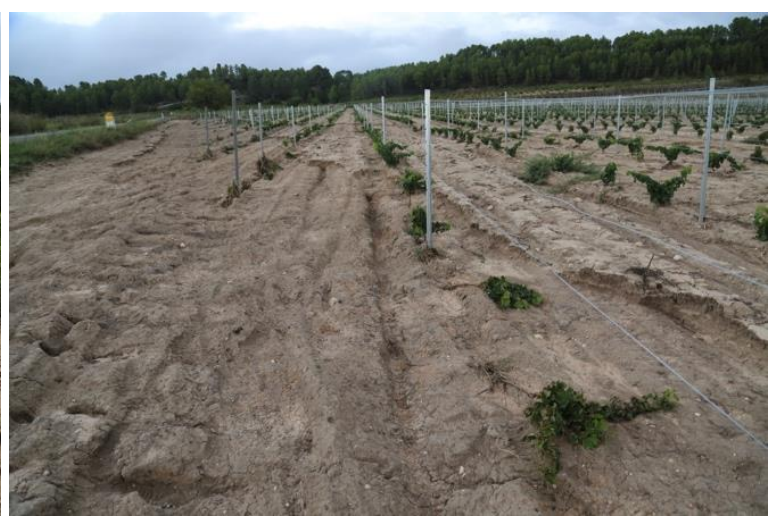

(b)

Figure 8. Cont. 


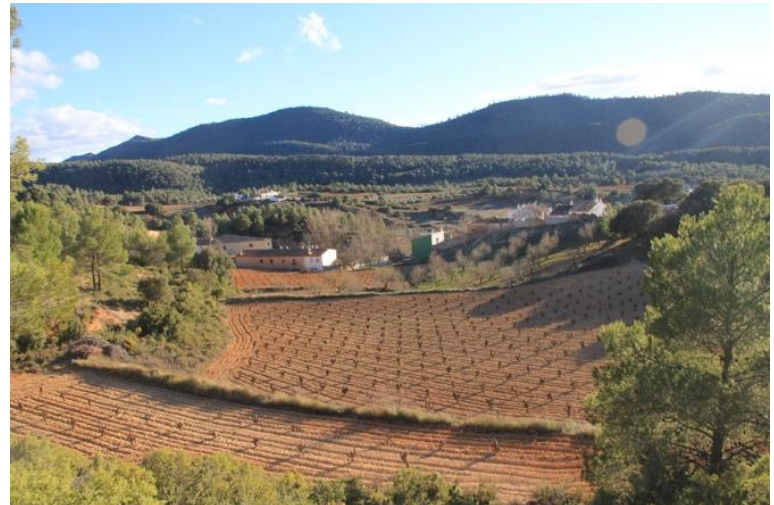

(c)

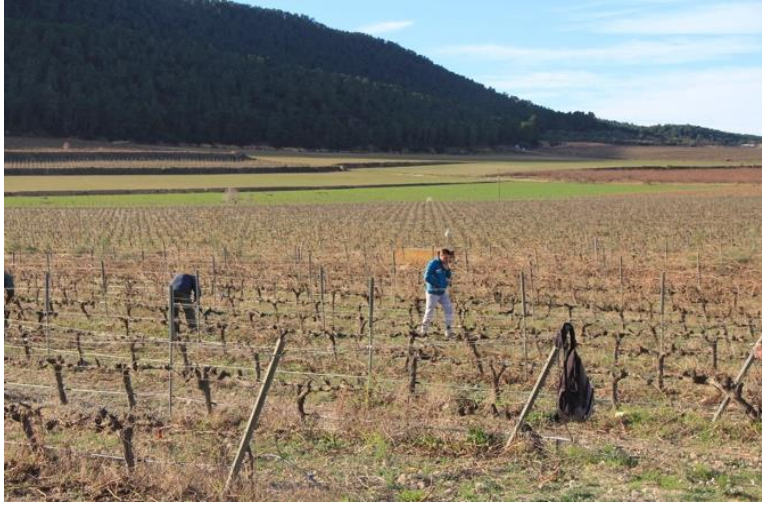

(d)

Figure 8. Sediment collected at the bottom of the slope after a thunderstorm in September 2018 in a vineyard in Fontanars dels Alforins (a) and in a young vineyard in Font de la Figuera (b). (c), recent vineyards landscape in Requena; (d), recent organic wine farming in Moixent.

Ensuring the sustainable development of rural areas is also necessary today, adapting suitable agricultural practices by type of cultivation [70-74] with the purpose of preserving soil quality and properties $[23,61,75-78]$. In the future, careful study of the socioeconomic impact on land-use change at regional scales and on global environments will be crucial to join investigations of life material's physical, chemical, and biological procedures in land cover $[36,40,48,54,60,62]$.

\section{Conclusions}

The present work reflects on how to analyze vineyards, given their recent economic success and expansion in agricultural landscapes, and especially given their predisposition to make agricultural land more sensitive to the processes of soil erosion, compared to other crops. One of the main challenges of this rural context is to balance the needs of wine production, as a major socioeconomic activity [2,56,60], with environmental impacts on the landscape [8]. The method allows for the identification of areas that allow further development of wine production without compromising environmental protection objectives. Taking a picture of their current state, planting age exposed the areas more sensitive to the development of soil degradation. Due to the recent phenomena of climate change (e.g., very hot summers and intense storms) the approach offered in this paper is meant to be a springboard for improving the sustainable development of Mediterranean agricultural landscapes dominated by vineyards.

Author Contributions: Conceptualization, I.Z. and A.C.; methodology, L.S.; validation, S.C.; formal analysis, I.Z. and L.S.; data curation, A.C.; writing-original draft preparation, I.Z., A.C. and L.S.; writing-review and editing, I.Z., L.S. and A.C.

Acknowledgments: Thank to José Antonio Franco, head of the Agrarian Studies Service at the Generalitat Valenciana, who assisted I.Z. during her fellowship as Visiting PhD Student at the Universitat de Valencia.

Conflicts of Interest: The authors declare no conflict of interest.

\section{References}

1. Mariani, A.; Vastola, A. Sustainable winegrowing: Current perspectives. Int. J. Wine Res. 2015, 7, 37-48. [CrossRef]

2. Zambon, I.; Colantoni, A.; Cecchini, M.; Mosconi, E.M. Rethinking sustainability within the viticulture realities integrating economy, landscape and energy. Sustainability 2018, 10, 320. [CrossRef]

3. Rodrigo-Comino, J.; Brevik, E.C.; Cerdà, A. The age of vines as a controlling factor of soil erosion processes in Mediterranean vineyards. Sci. Total Environ. 2018, 616, 1163-1173. [CrossRef]

4. Van Leeuwen, C.; Seguin, G. The concept of terroir in viticulture. J. Wine Res. 2006, 17, 1-10. [CrossRef] 
5. Biasi, R.; Barbera, G.; Marino, E.; Brunori, E.; Nieddu, G. Viticulture as crucial cropping system for counteracting the desertification of coastal land. Acta Hortic. 2012, 931, 71-77.

6. Barbati, A.; Corona, P.; Salvati, L.; Gasparella, L. Natural forest expansion into suburban countryside: Gained ground for a green infrastructure? Urban For. Urban Green. 2013, 12, 36-43. [CrossRef]

7. Biasi, R.; Brunori, E. The on-farm conservation of grapevine (Vitis vinifera L.) landraces assures the habitat diversity in the viticultural agro-ecosystem. VITIS-J. Grapevine Res. 2015, 54, 265-269.

8. Biasi, R.; Brunori, E.; Smiraglia, D.; Salvati, L. Linking traditional tree-crop landscapes and agro-biodiversity in Central Italy using a database of typical and traditional products: A multiple risk assessment through a data mining analysis. Biodivers. Conserv. 2015, 24, 3009-3031. [CrossRef]

9. Egea, P.; y Pérez, L.P. Sustainability and multifunctionality of protected designations of origin of olive oil in Spain. Land-Use Policy 2016, 58, 264-275. [CrossRef]

10. Kallas, Z.; Gómez-Limón, J.A.; Arriaza, M. Are citizens willing to pay for agricultural multifunctionality? Agric. Econ. 2007, 36, 405-419. [CrossRef]

11. Lovell, S.T.; Nathan, C.A.; Olson, M.B.; Mendez, V.E.; Kominami, H.C.; Erickson, D.L.; Morris, W.B. Integrating agroecology and landscape multifunctionality in Vermont: An evolving framework to evaluate the design of agroecosystems. Agric. Syst. 2010, 103, 327-341. [CrossRef]

12. Hall, A.; Louis, J.P.; Lamb, D.W. Low-resolution remotely sensed images of winegrape vineyards map spatial variability in planimetric canopy area instead of leaf area index. Aust. J. Grape Wine Res. 2008, 14, 9-17. [CrossRef]

13. Rodrigo Comino, J.; Keesstra, S.D.; Cerdà, A. Connectivity assessment in Mediterranean vineyards using improved stock unearthing method, LiDAR and soil erosion field surveys. Earth Surf. Process. Landf. 2018, 43, 2193-2206. [CrossRef]

14. Steinmaus, S.; Elmore, C.L.; Smith, R.J.; Donaldson, D.; Weber, E.A.; Roncoroni, J.A.; Miller, P.R.M. Mulched cover crops as an alternative to conventional weed management systems in vineyards. Weed Res. 2008, 48, 273-281. [CrossRef]

15. Brown, G.; Getz, D. Linking wine preferences to the choice of wine tourism destinations. J. Travel Res. 2005, 43, 266-276. [CrossRef]

16. Sánchez-Hernández, J.L.; Aparicio-Amador, J.; Alonso-Santos, J.L. The shift between worlds of production as an innovative process in the wine industry in Castile and Leon (Spain). Geoforum 2010, 41, 469-478. [CrossRef]

17. Fatorić, S.; Morén-Alegret, R.; Niven, R.J.; Tan, G. Living with climate change risks: stakeholders' employment and coastal relocation in mediterranean climate regions of Australia and Spain. Environ. Syst. Decis. 2017, 37, 276-288. [CrossRef]

18. Migliorini, P.; Gkisakis, V.; Gonzalvez, V.; Raigón, M.; Bàrberi, P. Agroecology in Mediterranean Europe: Genesis, state and perspectives. Sustainability 2018, 10, 2724. [CrossRef]

19. Salvati, L.; Carlucci, M. The economic and environmental performances of rural districts in Italy: Are competitiveness and sustainability compatible targets? Ecol. Econ. 2011, 70, 2446-2453. [CrossRef]

20. Zambon, I.; Benedetti, A.; Ferrara, C.; Salvati, L. Soil matters? A multivariate analysis of socioeconomic constraints to urban expansion in Mediterranean Europe. Ecol. Econ. 2018, 146, 173-183. [CrossRef]

21. Colantoni, A.; Ferrara, C.; Perini, L.; Salvati, L. Assessing trends in climate aridity and vulnerability to soil degradation in Italy. Ecol. Indic. 2015, 48, 599-604. [CrossRef]

22. Serpa, D.; Nunes, J.P.; Keizer, J.J.; Abrantes, N. Impacts of climate and land use changes on the water quality of a small Mediterranean catchment with intensive viticulture. Environ. Pollut. 2017, 224, 454-465. [CrossRef] [PubMed]

23. Bajocco, S.; Salvati, L.; Ricotta, C. Land degradation versus fire: A spiral process? Prog. Phys. Geogr. 2011, 35, 3-18. [CrossRef]

24. Salvati, L.; Bajocco, S.; Ceccarelli, T.; Zitti, M.; Perini, L. Towards a process-based evaluation of land vulnerability to soil degradation in Italy. Ecol. Indic. 2011, 11, 1216-1227. [CrossRef]

25. Salvati, L.; Gemmiti, R.; Perini, L. Land degradation in Mediterranean urban areas: An unexplored link with planning? Area 2012, 44, 317-325. [CrossRef]

26. Biddoccu, M.; Ferraris, S.; Opsi, F.; Cavallo, E. Long-term monitoring of soil management effects on runoff and soil erosion in sloping vineyards in Alto Monferrato (North-West Italy). Soil Tillage Res. 2016, 155, 176-189. [CrossRef] 
27. Biddoccu, M.; Ferraris, S.; Cavallo, E.; Opsi, F.; Previati, M.; Canone, D. Hillslope vineyard rainfall-runoff measurements in relation to soil infiltration and water content. Procedia Environ. Sci. 2013, 19, 351-360. [CrossRef]

28. Napoli, M.; Cecchi, S.; Orlandini, S.; Mugnai, G.; Zanchi, C.A. Simulation of fifield-measured soil loss in Mediterranean hilly areas (Chianti, Italy) with RUSLE. Catena 2016, 145, 246-256. [CrossRef]

29. Prosdocimi, M.; Cerdà, A.; Tarolli, P. Soil water erosion on Mediterranean vineyards: A review. Catena 2016, 141, 1-21. [CrossRef]

30. Rodrigo-Comino, J.R.; Iserloh, T.; Lassu, T.; Cerdà, A.; Keestra, S.D.; Prosdocimi, M.; Sinoga, J.R. Quantitative comparison of initial soil erosion processes and runoff generation in Spanish and German vineyards. Sci. Total Environ. 2016, 565, 1165-1174. [CrossRef]

31. Rodrigo-Comino, J.; Keesstra, S.; Cerdà, A. Soil Erosion as an Environmental Concern in Vineyards. The Case Study of Celler del Roure, Eastern Spain, by Means of Rainfall Simulation Experiments. Beverages 2018, 4, 31. [CrossRef]

32. Rodrigo-Comino, J. Five decades of soil erosion research in "terroir". The State-of-the-Art. Earth-Sci. Rev. 2018, 179, 436-447. [CrossRef]

33. Cerdà, A.; González-Pelayo, Ó.; Giménez-Morera, A.; Jordán, A.; Pereira, P.; Novara, A.; Brevik, E.C.; Prosdocimi, M.; Mahmoodabadi, M.; Keesstra, S.; et al. Use of barley straw residues to avoid high erosion and runoff rates on persimmon plantations in eastern Spain under low frequency-high magnitude simulat-ed rainfall events. Soil Res. 2016, 54, 154-165. [CrossRef]

34. Di Prima, S.; Rodrigo-Comino, J.; Novara, A.; Iovino, M.; Pirastru, M.; Keesstra, S.; Cerdà, A. Soil physical quality of citrus orchards under tillage, herbicide, and organic managements. Pedosphere 2018, 28, 463-477. [CrossRef]

35. Rodrigo-Comino, J.; Martínez-Hernández, C.; Iserloh, T.; Cerdà, A. Comparison of water soil erosion on Spanish Mediterannean abandoned land and agricultural fields under vine, almond, olives and citrus. Geophys. Res. Abstr. 2016, 19, EGU2017-286.

36. Taguas, E.V.; Ayuso, J.L.; Pérez, R.; Giráldez, J.V.; Gómez, J.A. Intra and inter-annual variability of runoff and sediment yield of an olive micro-catchment with soilprotection by natura 1 ground cover in southern Spain. Geoderma 2013, 206, 49-62. [CrossRef]

37. Taguas, E.V.; Guzmán, E.; Guzmán, G.; Vanwalleghem, T.; Gómez, J.A. Characteristics and importance of rill and gully erosion: A case study in a small catchment of a mar-ginal olive grove. Cuad. Investig. Geogr. 2015, 41, 107-126. [CrossRef]

38. Keesstra, S.; Pereira, P.; Novara, A.; Brevik, E.C.; Azorin-Molina, C.; Parras-Alcántara, L.; Jordán, A.; Cerdà, A. Effects of soil management techniques on soil water ero-sion in apricot orchards. Sci. Total Environ. 2016, 551-552, 357-366. [CrossRef]

39. Atucha, A.; Merwin, I.A.; Brown, M.G.; Gardiazabal, F.; Mena, F.; Adriazola, C.; Lehmann, J. Soil erosion, runoff and nutrient losses in an avocado (Persea americana Mill.) hillside orchard under different groundcover management systems. Plant Soil 2013, 368, 393-406. [CrossRef]

40. Novara, A.; Gristina, L.; Guaitoli, F.; Santoro, A.; Cerdà, A. Managing soil nitrate with cover crops and buffer strips in Sicilian vineyards. Solid Earth 2013, 4, 255-262. [CrossRef]

41. Preti, F.; Tarolli, P.; Dani, A.; Calligaro, S.; Prosdocimi, M. LiDAR derived high resolution topography: The next challenge for the analysis of terraces stability and vineyard soil erosion. J. Agric. Eng. 2013, 44. [CrossRef]

42. Prosdocimi, M.; Burguet, M.; Di Prima, S.; Sofia, G.; Terol, E.; Comino, J.R.; Tarolli, P. Rainfall simulation and Structure-from-Motion photogrammetry for the analysis of soil water erosion in Mediterranean vineyards. Sci. Total Environ. 2017, 574, 204-215. [CrossRef]

43. Rodrigo-Comino, J.R.; Senciales, J.M.; Ramos, M.C.; Martínez-Casasnovas, J.A.; Lasanta, T.; Brevik, E.C.; Sinoga, J.R. Understanding soil erosion processes in Mediterranean sloping vineyards (Montes de Málaga, Spain). Geoderma 2017, 296, 47-59. [CrossRef]

44. Rodrigo-Comino, J.; Cerdà, A. Improving stock unearthing method to measure soil erosion rates in vineyards. Ecol. Indic. 2018, 85, 509-517. [CrossRef]

45. Rodrigo-Comino, J.; Wirtz, S.; Brevik, E.C.; Ruiz-Sinoga, J.D.; Ries, J.B. Assessment of agri-spillways as a soil erosion protection measure in Mediterranean sloping vineyards. J. Mt. Sci. 2017, 14, 1009-1022. [CrossRef] 
46. Cerdà, A.; Keesstra, S.D.; Rodrigo-Comino, J.; Novara, A.; Pereira, P.; Brevik, E.; Giménez-Morera, A.; Fernández-Raga, M.; Pulido, M.; di Prima, S.; et al. Runoff initiation, soil detachment and connectivity are enhanced as a consequence of vineyards plantations. J. Environ. Manag. 2017, 202, 268-275. [CrossRef] [PubMed]

47. Tarolli, P.; Sofia, G.; Calligaro, S.; Prosdocimi, M.; Preti, F.; Dalla Fontana, G. Erosion in vineyards and LiDAR: New opportunities for anthropogenic terraced landscapes. In Proceedings of the EGU General Assembly 2014, Vienna, Austria, 27 April-2 May 2014.

48. García-Díaz, A.; Bienes, R.; Sastre, B.; Novara, A.; Gristina, L.; Cerdà, A. Nitrogen losses in vineyards under different types of soil groundcover. A fifield runoff simulator ap-proach in central Spain. Agric. Ecosyst. Environ. 2017, 236, 256-267. [CrossRef]

49. Martínez-Casasnovas, J.A.; Ramos, M.C.; Ribes-Dasi, M. Soil erosion caused by ex-treme rainfall events: Mapping and quantifification in agricultural plots from very de-tailed digital elevation models. Geoderma 2002, 105, 125-140. [CrossRef]

50. Novara, A.; Gristina, L.; Saladino, S.S.; Santoro, A.; Cerdà, A. Soil erosion assessment on tillage and alternative soil managements in a Sicilian vineyard. Soil Tillage Res. 2011, 117, 140-147. [CrossRef]

51. Martínez-Casasnovas, J.A.; Ramos, M.C. The cost of soil erosion in vineyard fields in the Penedès-Anoia Region (NE Spain). Catena 2006, 68, 194-199. [CrossRef]

52. Kirchhoff, M.; Rodrigo-Comino, J.; Seeger, M.; Ries, J.B. Soil erosion in sloping vineyards under conventional and organic land-use managements (Saar-Mosel valley, Germany). Cuad. Investig. Geogr. 2017, 43, 119-140. [CrossRef]

53. García, F.M.; Ramos, A.B.; Riquelme, F.M.; Carsjens, G.J. A territorial approach to assess the transition to trellis vineyards in special protection areas for steppe birds in Spain. Land-Use Policy 2017, 67, $27-37$.

54. Ferrara, A.; Salvati, L.; Sabbi, A.; Colantoni, A. Soil resources, land cover changes and rural areas: Towards a spatial mismatch? Sci. Total Environ. 2014, 478, 116-122. [CrossRef]

55. Genet, M.; Kokutse, N.; Stokes, A.; Fourcaud, T.; Cai, X.; Ji, J.; Mickovski, S. Root reinforcement in plantations of Cryptomeria japonica D. Don: Effect of tree age and stand structure on slope stability. For. Ecol. Manag. 2008, 256, 1517-1526. [CrossRef]

56. Carbone, A.; Quici, L.; Pica, G. The Age Dynamics of Vineyards: Past Trends Affecting the Future; Wine Economics and Policy; Elsevier: Amsterdam, The Netherlands, 2019.

57. Eurostat. Agriculture, Forestry and Fishery Statistics, 2015 ed.; Publications Office of the European Union: Luxembourg, 2016.

58. Clavel, M.; Fernández-Ortiz, R.; Arteaga-Ortiz, J.; Valencia, H. A resource-based analysis of the internationalisation process of Spanish wineries. Eur. J. Int. Manag. 2017, 11, 19-41. [CrossRef]

59. Clemente-Ricolfe, J.S.; Escribá-Pérez, C.; Rodriguez-Barrio, J.E.; Buitrago-Vera, J.M. The potential wine tourist market: The case of Valencia (Spain). J. Wine Res. 2012, 23, 185-202. [CrossRef]

60. Basso, M. Land-use changes triggered by the expansion of wine-growing areas: A study on the Municipalities in the Prosecco's production zone (Italy). Land Use Policy 2019, 83, 390-402. [CrossRef]

61. Ceccarelli, T.; Bajocco, S.; Luigi Perini, L.; Luca Salvati, L. Urbanisation and land take of high-quality agricultural soils-exploring long-term land use changes and land capability in Northern Italy. Int. J. Environ. Res. 2014, 8, 181-192.

62. Pan, D.; Domon, G.; De Blois, S.; Bouchard, A. Temporal (1958-1993) and spatial patterns of land-use changes in Haut-Saint-Laurent (Quebec, Canada) and their relation to landscape physical attributes. Landsc. Ecol. 1999, 14, 35-52. [CrossRef]

63. Keesstra, S.; Mol, G.; de Leeuw, J.; Okx, J.; de Cleen, M.; Visser, S. Soil-related sustainable development goals: Four concepts to make land degradation neutrality and restoration work. Land 2018, 7, 133. [CrossRef]

64. Contador, J.L.; Schnabel, S.; Gutiérrez, A.G.; Fernández, M.P. Mapping sensitivity to land degradation in Extremadura, SW Spain. Land Degrad. Dev. 2009, 20, 129-144. [CrossRef]

65. Vaudour, E. The quality of grapes and wine in relation to geography: Notions of terroir at various scales. J. Wine Res. 2002, 13, 117-141. [CrossRef]

66. Zhu, X.; Moriondo, M.; van Ierland, E.C.; Trombi, G.; Bindi, M. A model-based assessment of adaptation options for Chianti wine production in Tuscany (Italy) under climate change. Reg. Environ. Chang. 2016, 16, 85-96. [CrossRef] 
67. Bienes, R.; Pérez, M.J.M.; Colmenero, M.R. Cultivos herbáceos, viñedos y olivares: El manejo tradicional del suelo y sus consecuencias en la erosión hídrica. Cuad. Investig. Geogr. 2012, 38, 49-74. [CrossRef]

68. López-Piñeiro, A.; Muñoz, A.; Zamora, E.; Ramírez, M. Influence of the management regime and phenological state of the vines on the physicochemical properties and the seasonal fluctuations of the microorganisms in a vineyard soil under semi-arid conditions. Soil Tillage Res. 2013, 126, 119-126. [CrossRef]

69. Ruiz-Sinoga, J.D.; Garcia-Marin, R.; Gabarron-Galeote, M.A.; Martinez-Murillo, J.F. Analysis of dry periods along a pluviometric gradient in Mediterranean southern Spain. Int. J. Climatol. 2012, 32, 1558-1571. [CrossRef]

70. Anifantis, A.S.; Colantoni, A.; Pascuzzi, S. Thermal energy assessment of a small scale photovoltaic, hydrogen and geothermal stand-alone system for greenhouse heating. Renew. Energy 2017, 103, 115-127. [CrossRef]

71. Cecchini, M.; Cossio, F.; Marucci, A.; Monarca, D.; Colantoni, A.; Petrelli, M.; Allegrini, E. Survey on the status of enforcement of European directives on health and safety at work in some Italian farms. J. Food Agric. Environ 2013, 11, 595-600.

72. Febbi, P.; Menesatti, P.; Costa, C.; Pari, L.; Cecchini, M. Automated determination of poplar chip size distribution based on combined image and multivariate analyses. Biomass Bioenergy 2015, 73, 1-10. [CrossRef]

73. Moscetti, R.; Radicetti, E.; Monarca, D.; Cecchini, M.; Massantini, R. Near infrared spectroscopy is suitable for the classification of hazelnuts according to Protected Designation of Origin. J. Sci. Food Agric. 2015, 95, 2619-2625. [CrossRef]

74. Colantoni, A.; Cecchini, M.; Monarca, D.; Bedini, R.; Riccioni, S. The risk of musculoskeletal disorders due to repetitive movements of upper limbs for workers employed in hazelnut sorting. J. Agric. Eng. 2013, 44. [CrossRef]

75. Colantoni, A.; Grigoriadis, E.; Sateriano, A.; Venanzoni, G.; Salvati, L. Cities as selective land predators? A lesson on urban growth, deregulated planning and sprawl containment. Sci. Total Environ. 2016, 545, 329-339. [CrossRef] [PubMed]

76. Colantoni, A.; Monarca, D.; Cecchini, M.; Mosconi, E.; Poponi, S. Small-Scale Energy Conversion of Agro-Forestry Residues for Local Benefits and European Competitiveness. Sustainability 2019, 11, 10. [CrossRef]

77. Duvernoy, I.; Zambon, I.; Sateriano, A.; Salvati, L. Pictures from the other side of the fringe: Urban growth and peri-urban agriculture in a post-industrial city (Toulouse, France). J. Rural Stud. 2018, 57, 25-35. [CrossRef]

78. Salvati, L. Monitoring high-quality soil consumption driven by urban pressure in a growing city (Rome, Italy). Cities 2013, 31, 349-356. [CrossRef] 